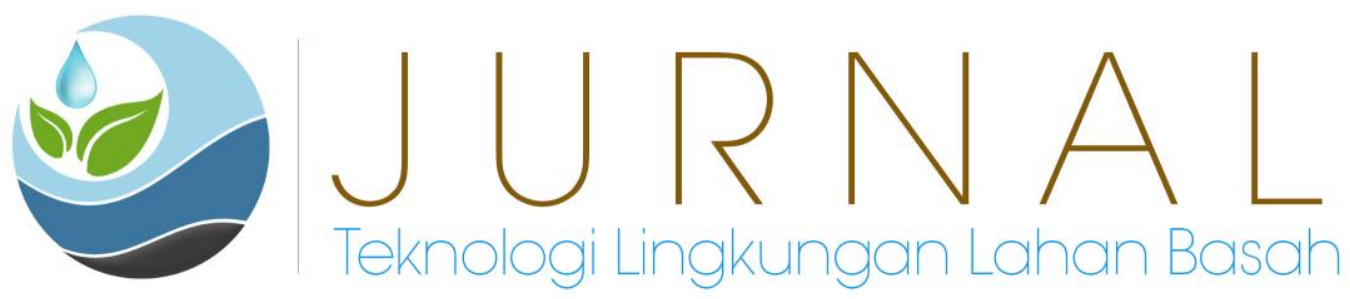

\title{
Perbandingan Efisiensi Cascade Aerator dan Bubble Aerator dalam Menurunkan Kadar Besi Air Sumur Bor
}

\author{
Utri Diansari $^{1}$, Rizki Purnaini ${ }^{2}$, dan Govira Christiadora Asbanu ${ }^{2}$ \\ ${ }^{1}$ Jurusan Teknik Lingkungan Universitas Tanjungpura \\ ${ }^{2}$ Kelompok Keahlian Teknologi dan Rekayasa Lingkungan Fakultas Teknik \\ Universitas Tanjungpura \\ E-mail : utridian03@gmail.com
}

\begin{abstract}
One source of clean water that is widely used by Indonesians is groundwater from drilled well water. Drilled well water in Pal Sembilan Village, Sungai Kakap District, Kubu Raya Regency, has an Fe content of 21.05 mg / L, which means it exceeds the quality standard based on PerMenKes No. 32 of 2017. The purpose of this study was to compare the effect of using a cascade aerator and bubble aerator to reduce Fe levels in borehole water, determine the efficiency of reducing Fe levels in borehole water and determine the optimum contact time for cascade aerators and bubble aerators to reduce Fe levels in well water. This type of research is a quasy experiment with 3 repetitions for each aeration method. The research sample was taken by using the grab sampling technique, the aeration process was carried out in one of the residents' houses and iron levels were checked in the laboratory. Based on the research that has been done, there is a difference between the cascade aerator and the bubble aerator, where the cascade aerator is more effective in reducing Fe levels in bore well water. The efficiency of reducing Fe levels in bore well water using a cascade aerator is $50.45 \%$ with an optimum contact time of 28 minutes and the efficiency for reducing Fe levels in bore well water using a bubble aerator is $6.13 \%$ with an optimum contact time of 40 minutes.
\end{abstract}

Keywords: Aeration, Iron (Fe), Drilling Well

\begin{abstract}
Abstrak
Salah satu sumber air bersih yang banyak digunakan oleh masyarakat Indonesia adalah air tanah dari air sumur bor. Air sumur bor di Kelurahan Pal Sembilan, Kecamatan Sungai Kakap, Kabupaten Kubu Raya, mempunyai kadar Fe sebesar 21,05 mg/L, yang berarti melebihi baku mutu berdasarkan PerMenKes No. 32 Tahun 2017. Tujuan penelitian ini adalah membandingkan pengaruh penggunaan cascade aerator dan bubble aerator untuk menurunkan kadar Fe dalam air sumur bor, mengetahui besar efisiensi penurunan kadar Fe dalam air sumur bor dan mengetahui waktu kontak optimum cascade aerator dan bubble aerator untuk menurunkan kadar Fe dalam air sumur bor. Jenis penelitian ini adalah quasy experiment dengan pengulangan sebanyak 3 kali untuk setiap metode aerasi. Sampel penelitian diambil dengan teknik grab sampling, proses aerasi dilakukan di salah satu rumah warga dan pemeriksaan kadar besi di laboratorium. Berdasarkan penelitian yang telah dilakukan, ada perbedaan antara cascade aerator dengan bubble aerator, dimana cascade aerator lebih efektif dalam menurunkan kadar Fe dalam air sumur bor. Besar efisiensi penurunan kadar Fe dalam air sumur bor dengan menggunakan cascade aerator sebesar 50,45\% dengan waktu kontak optimum 28 menit dan besar efisiensi penurunan kadar Fe dalam air sumur bor dengan menggunakan bubble aerator sebesar 6,13\% dengan waktu kontak optimum 40 menit.
\end{abstract}

Kata Kunci: Aerasi, Besi (Fe), Sumur Bor 


\section{PENDAHULUAN}

Salah satu sumber air bersih yang banyak digunakan oleh masyarakat Indonesia adalah air tanah dari sumur bor. Namun, penggunaan air sumur bor perlu memperhatikan beberapa parameter kimia yang harus sesuai standar diantaranya adalah besi ( $\mathrm{Fe})$. Air bersih dengan konsentrasi Fe yang melebihi baku mutu dapat membawa dampak negatif bagi masyarakat, seperti gangguan kesehatan, merusak pakaian dan perabotan rumah tangga yang terbuat dari logam. Akumulasi Fe dalam tubuh menyebabkan efek kronik seperti hemokromatosis (kelebihan zat besi yang terakumulasi dalam hati, jantung dan pankreas) (Joko, 2010).

Air sumur bor di Kelurahan Pal Sembilan, Kecamatan Sungai Kakap, Kabupaten Kubu Raya, memiliki kandungan besi sebesar 21,05 mg/L. Berdasarkan nilai kandungan maksimum untuk parameter besi menurut Peraturan Menteri Kesehatan No. 32 tahun 2017 tentang Standar Baku Mutu Kesehatan Lingkungan dan Persyaratan Kesehatan Air untuk Keperluan Higiene Sanitasi, Kolam Renang, Solus Per Aqua, dan Pemandian Umum nilai maksimum untuk besi $1 \mathrm{mg} / \mathrm{L}$.

Salah satu teknologi tepat guna yang mudah untuk diaplikasi di masyarakat adalah penggunaan cascade aerator dan bubble aerator untuk menurunkan kadar Fe dalam air sumur bor. Pada cascade aerator, teknis pembuatannya cukup sederhana dengan biaya tidak terlalu mahal dan mudah dilaksanakan, yaitu air dilewatkan pada susunan penampang bertingkat secara gravitasi. Metode cascade aerator ini mampu menaikkan oksigen 60-80 \% dari jumlah oksigen yang tertinggi pada air (Hartini, 2012). Sedangkan pada bubble aerator, digunakan mesin aerator yang dapat dibeli secara langsung di toko dan praktis untuk digunakan. Tujuan yang ingin dicapai dalam penelitian ini adalah membandingkan pengaruh penggunaan cascade aerator dan bubble aerator untuk menurunkan kadar Fe dalam air sumur bor, mengetahui besar efisiensi penurunan kadar Fe dan mengetahui waktu kontak optimum cascade aerator dan bubble aerator.

\section{METODE PENELITIAN}

\section{A. Lokasi dan Waktu Penelitian}

Penelitian dilakukan dari bulan Juli hingga bulan Agustus 2020. Pengambilan sampel air sumur dan tempat pembuatan alat serta tempat running alat aerasi dengan menggunakan cascade aerator dan bubble aerator berada di rumah warga Jalan Perdamaian Komplek Ari Karya Indah IV Jalur 2 Blok G Kelurahan Pal Sembilan, Kecamatan Sungai Kakap, Kabupaten Kubu Raya. Pengujian kadar besi air sumur bor dilaksanakan di Laboratorium Fakultas Pertanian Universitas Tanjungpura.

\section{B. Alat dan Bahan Penelitian}

Alat yang digunakan pada penelitian ini antara lain palu, gergaji, meteran, pompa, pompa aerator, bubble aerator, gunting, cutter (pemotong), DO meter, barometer, termometer dan stopwatch (alat ukur waktu). Bahan yang digunakan antara lain kayu reng $4 \times 6$, rivet (fiber dari plastik), pipa PVC 1 inch, elbow 90 , paku, botol plastik $600 \mathrm{ml}$, bak penampung $100 \mathrm{~L}$, lem, selang ukuran $1 / 4$, keran dan drat ukuran $3 / 4$.

\section{Pengambilan Sampel Air Sumur}

Pengambilan sampel air sebanyak 100 L dilakukan dengan metode grab sampling yaitu sampel yang diambil secara langsung dari sumur yang sudah ditentukan. 


\section{Proses Aerasi Menggunakan Cascade Aerator}

Aerator ini dirancang untuk proses aerasi dengan debit $0,5 \mathrm{~m}^{3} /$ detik dan variasi waktu running 20, 30 dan 40 menit dengan waktu kontak 12, 20 dan 28 menit dari setiap waktu running. Dimensi aerator yang dirancang memiliki panjang $50 \mathrm{~cm}$ dan tinggi maupun lebar tiap lempengan/plat $30 \mathrm{~cm}$ dengan jumlah step keseluruhan adalah $5 \mathrm{step}$, sehingga total ketinggian 1,5 meter dan luas permukaannya $0,78 \mathrm{~m}^{2}$. Sebelum dilakukan aerasi, air sumur bor diperiksa kadar DO dan Fe terlebih dahulu untuk dibandingkan dengan Peraturan Menteri Kesehatan Nomor 32 Tahun 2017. Setelah itu air tersebut diaerasi dengan variasi waktu 20, 30 dan 40 menit, dan air yang telah turun melewati step cascade dipompa kembali menuju tandon. Langkah tersebut dilakukan sebanyak tiga kali atau triplo. Setelah proses aerasi selesai, kadar DO dan Fe diperiksa kembali. Langkah tersebut dilakukan untuk semua variasi waktu kontak aerasi.

\section{E. Proses Aerasi Menggunakan Bubble Aerator}

Air sumur bor ditampung dalam bak berkapasitas 100 liter dengan ukuran diameter 46 $\mathrm{cm}$ dan tinggi $80 \mathrm{~cm}$. Sebelum dilakukan aerasi, air tersebut diperiksa kadar DO dan Fe terlebih dahulu yang kemudian dibandingkan dengan Peraturan Menteri Kesehatan Nomor 32 Tahun 2017. Kontakan udara pada air dengan menggunakan alat bubble aerator ke dalam bak dan biarkan dengan variasi waktu kontak 20, 30 dan 40 menit. Pada proses aerasi menggunakan bubble aerator dilakukan pengulangan sebanyak 3 kali atau triplo. Setelah proses aerasi selesai, kemudian diperiksa kadar DO dan Fe. Langkah tersebut dilakukan untuk semua variasi waktu kontak aerasi.

\section{F. Cara Pengumpulan Data}

Data yang dikumpulkan meliputi data primer dan sekunder dengan jenis penelitian Quasy Experiment atau bersifat eksperimen semu. Quasy Experiment adalah percobaan yang bertujuan untuk mengetahui suatu gejala atau pengaruh yang timbul, sebagai akibat dari adanya perlakuan tertentu. Data akan dianalisis secara statistik deskriptif dan secara SPSS (Statistical Product and Service Solutions), analisis yang menggunakan SPSS yaitu analisis independent sampel test dan regresi linear sederhana. Data kemudian disajikan dalam bentuk tabel dan grafik berikut penjelasannya.

\section{HASIL DAN PEMBAHASAN}

\section{A. Efisiensi Penyisihan Kadar Fe Dengan Cascade Aerator}

Penelitian ini melakukan analisis kadar besi (Fe) air sumur bor dengan variasi waktu kontak. Variasi waktu kontak dapat menunjukkan waktu yang efektif untuk menurunkan kadar besi dalam air sumur bor. Pengujian air sumur bor menggunakan metode aerasi cascade aerator dilakukan sebanyak tiga kali. Hasil analisa Fe pada cascade aerator dapat dilihat pada Tabel 1 . 
Tabel 1. Hasil Pemeriksaan Fe Air Sumur Bor Dengan Menggunakan Cascade Aerator

\begin{tabular}{|c|c|c|c|c|c|}
\hline \multirow{2}{*}{ Sampel } & \multicolumn{4}{|c|}{$\begin{array}{c}\text { Kadar Fe (mg/liter) } \\
\text { Cascade Aerator }\end{array}$} \\
\cline { 2 - 5 } & $\begin{array}{c}\text { Standar Yang } \\
\text { Diizinkan } \\
\text { Berdasarkan } \\
\text { Aerasi }\end{array}$ & $\begin{array}{c}\text { Setelah } \\
\text { 12 Menit }\end{array}$ & $\begin{array}{c}\text { Setelah } \\
\text { 20 Menit }\end{array}$ & $\begin{array}{c}\text { Setelah } \\
\text { 28 Menit }\end{array}$ & 32 Tahun 2017 \\
\hline C1 & 21,05 & 16,71 & 16,67 & 10,43 & \\
\hline C2 & 21,05 & 16,30 & 14,55 & 10,43 & \multirow{2}{*}{$1 \mathrm{mg} / \mathrm{L}$} \\
\hline C3 & 21,05 & 16,71 & 11,99 & 11,01 & \\
\hline Rata-rata & 21,05 & 16,57 & 14,40 & 10,62 & \\
\hline
\end{tabular}

Keterangan :

$\mathrm{C} 1=$ cascade aerator perlakuan pertama

$\mathrm{C} 2$ = cascade aerator perlakuan kedua

$\mathrm{C} 3$ = cascade aerator perlakuan ketiga

Berdasarkan hasil penelitian dan analisis laboratorium, diketahui kadar Fe dalam sumur bor sebelum perlakuan dengan proses aerasi menggunakan cascade aerator sebesar 21,05 $\mathrm{mg} / \mathrm{L}$, yang berarti melebihi baku mutu menurut Peraturan Menteri Kesehatan No.32 Tahun 2017 yaitu $1 \mathrm{mg} / \mathrm{L}$. Salah satu penyebab kadar besi dalam air tinggi yaitu tercemar oleh gas korosif seperti $\mathrm{CO}_{2}$ dan $\mathrm{H}_{2} \mathrm{~S}$. Gas korosif tersebut berbahaya karena sesuai dengan namanya, bersifat korosif dan partikel-partikelnya bercampur dalam air. Nilai kadar Fe turun setelah melakukan proses aerasi karena cascade aerator memaksimalkan terjadinya kontak air dengan udara, penangkapan udaranya terjadi pada saat air terjun dari lempengan-lempengan trap yang membawanya. Oksigen kemudian dipindahkan dari gelembung-gelembung udara ke dalam air, sehingga oksigen terlarut semakin banyak yang dapat menurunkan kadar Fe karena proses oksidasi dengan oksigen dalam air.

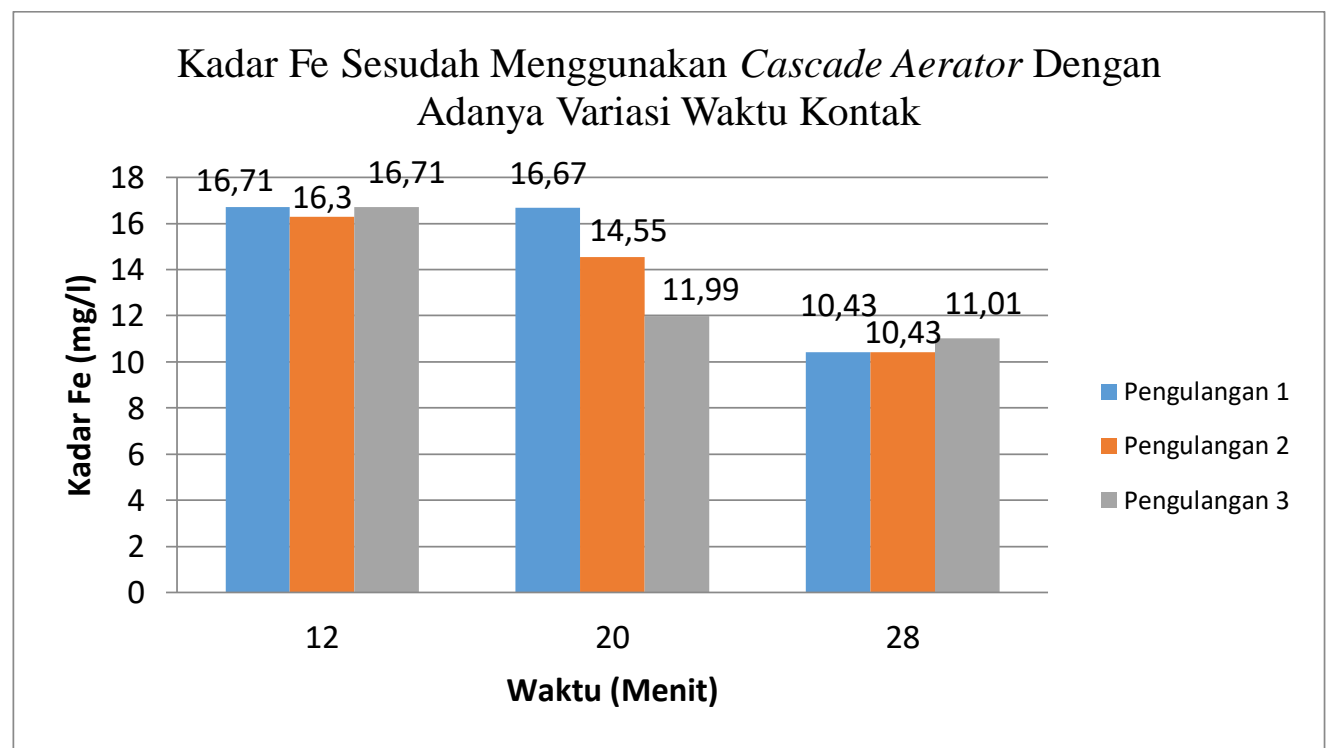

Gambar 1. Grafik Kadar Fe Sesudah Menggunakan Cascade Aerator dengan Adanya Variasi Waktu Kontak

Kadar Fe setelah perlakuan menggunakan cascade aerator dengan variasi waktu running 20, 30 dan 40 menit, dimana waktu kontak masing-masing dari waktu running 12, 20 dan 28 menit dengan 3 kali pengulangan menunjukkan pada waktu 40 menit mengalami penurunan kadar besi sebesar 10,43 $\mathrm{mg} / \mathrm{L}$ pada pengulangan pertama dan pengulangan kedua. Hal ini dapat terjadi karena jumlah cascade aerator yang digunakan ada 5 tangga, sehingga penetrasi air dan oksigen sangat besar dan kontak antara oksigen dan Fe dalam 
air berlangsung lebih sering. Dari hasil penelitian sebelumnya oleh Eko Hartini (2012) didapatkan bahwa cascade aerator 10 step mampu menurunkan kadar Mn air sumur gali dengan rata-rata $0,02 \mathrm{mg} / \mathrm{L}$, efektivitas sebesar $98,74 \%$. Untuk efisiensi penurunan kadar Fe pada cascade aerator dapat dilihat pada Tabel 2.

Tabel 2. Efisiensi Metode Aerasi Cascade Aerator Terhadap Penurunan Kadar Fe Dalam Air Sumur Bor

\begin{tabular}{|c|c|c|c|c|}
\hline \multirow{2}{*}{$\begin{array}{c}\text { Waktu } \\
\text { (Menit) }\end{array}$} & \multicolumn{2}{|c|}{ Efisiensi Metode Aerasi Cascade Aerator (\%) } & \multirow{2}{*}{ Rata-rata } \\
\cline { 2 - 4 } & $\mathbf{C 1}$ & $\mathbf{C 2}$ & $\mathbf{C 3}$ & \\
\hline $\mathbf{1 2}$ & 20,62 & 22,57 & 20,62 & 21,27 \\
\hline $\mathbf{2 0}$ & 20,81 & 30,88 & 43,04 & 31,58 \\
\hline $\mathbf{2 8}$ & 50,45 & 50,45 & 47,70 & 49,53 \\
\hline
\end{tabular}

Berdasarkan hasil pada Tabel.2, cascade aerator memberikan hasil yang lebih baik dalam menurunkan kadar Fe air sumur bor dengan efisiensi yang paling tinggi sebesar 50,45 \% dirunning pertama dan running kedua dengan waktu kontak 28 menit, rata-rata nilai efisiensi waktu kontak 28 menit yaitu 49,53\%. Waktu kontak 28 menit merupakan waktu yang optimum dalam menurunkan kadar Fe air sumur bor karena nilai efisiensinya lebih besar dibanding nilai efisiensi waktu 12 menit dan 28 menit.

Berdasarkan penelitian Hartini (2012), metode cascade aerator mampu menaikkan oksigen 60-80 \% dari jumlah oksigen yang tertinggi pada air. Pada penelitian ini nilai efisiensi yang paling tinggi 50,45\% tidak sampai $60 \%$. Hal ini dimungkinkan karena adanya penggunaan fiber plastik yang melapisi setiap anak tangga cascade aerator, sehingga kontak udaranya lebih cepat dan dapat mempengaruhi nilai efisiensi menjadi lebih rendah.

\section{B. Efisiensi Penyisihan Kadar Fe Dengan Bubble Aerator}

Penentuan efisiensi penyisihan kadar Fe dengan menggunakan metode bubble aerator dilakukan dengan pengujian air sumur bor yang dilakukan sebanyak 3 kali. Hasil analisa Fe pada bubble aerator dapat dilihat pada Tabel 3.

Tabel 3. Hasil Pemeriksaan Fe Air Sumur Bor Dengan Menggunakan Bubble Aerator

\begin{tabular}{|c|c|c|c|c|c|}
\hline \multirow{2}{*}{ Sampel } & \multicolumn{4}{|c|}{$\begin{array}{c}\text { Kadar Fe (mg/liter) } \\
\text { Bubble Aerator }\end{array}$} & \multirow{2}{*}{$\begin{array}{c}\text { Standar Yang } \\
\text { Diizinkan } \\
\text { Berdasarkan } \\
\text { PerMenKes No. } \\
\text { 32 Tahun } 2017\end{array}$} \\
\hline & $\begin{array}{c}\text { Sebelum } \\
\text { Aerasi }\end{array}$ & $\begin{array}{c}\text { Setelah } \\
20 \text { Menit }\end{array}$ & $\begin{array}{l}\text { Setelah } \\
\text { 30 Menit }\end{array}$ & $\begin{array}{l}\text { Setelah } \\
40 \text { Menit }\end{array}$ & \\
\hline B1 & 21,05 & 20,59 & 20,33 & 19,76 & \multirow{4}{*}{$1 \mathrm{mg} / \mathrm{L}$} \\
\hline B2 & 21,05 & 20,95 & 20,74 & 20,15 & \\
\hline B3 & 21,05 & 20,91 & 20,70 & 20,33 & \\
\hline $\begin{array}{l}\text { Rata- } \\
\text { rata }\end{array}$ & 21,05 & 20,82 & 20,59 & 20,08 & \\
\hline
\end{tabular}

Keterangan :

$\mathrm{B} 1$ = bubble aerator perlakuan pertama

$\mathrm{B} 2=$ bubble aerator perlakuan kedua

$\mathrm{B} 3$ = bubble aerator perlakuan ketiga

Setelah perlakuan proses aerasi dan dengan adanya variasi kontak, kadar Fe mengalami penurunan, rata-rata nilai kadar Fe menggunakan bubble aerator setelah waktu kontak 20, 30 dan 40 menit masing-masing sebesar 20,82 mg/L, 20,59 mg/L dan 20,08 mg/L. 
Diantara dua aerator yang digunakan dengan variasi kontak 20, 30 dan 40 menit, cascade aerator memberikan hasil yang lebih baik dibandingkan bubble aerator. Namun, penurunan kadar Fe dengan menggunakan cascade aerator belum sesuai dengan baku mutu menurut Peraturan Menteri Kesehatan No.32 Tahun 2017 yaitu 1 mg/L. Sehingga diperlukan pengolahan lanjutan untuk menurunkan kadar besi hingga memenuhi standar baku mutu air bersih yaitu dengan menambahkan proses filtrasi.

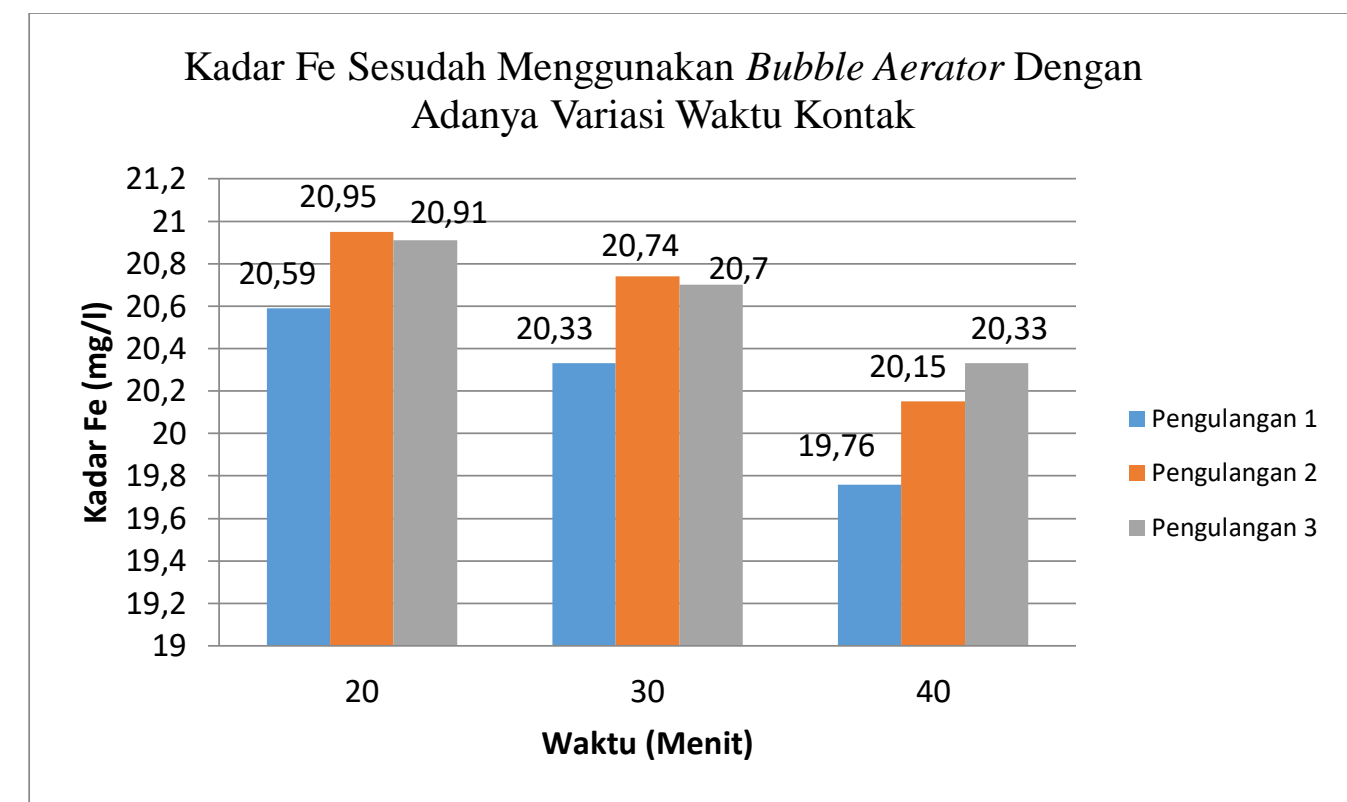

Gambar 2. Grafik Kadar Fe Sesudah Menggunakan Bubble Aerator Dengan Adanya Variasi Waktu Kontak

Kadar Fe setelah perlakuan menggunakan bubble aerator dengan variasi waktu kontak 20, 30, dan 40 menit pada 3 kali pengulangan menunjukkan kadar Fe yang paling banyak mengalami penurunan pada waktu 40 menit di pengulangan pertama sebesar 19,76 mg/L. Hasil ini tentunya belum sesuai atau bahkan masih jauh dengan nilai standar baku mutu PerMenKes No. 32 Tahun 2017, kemungkinan disebabkan oleh kurang meratanya hembusan oksigen yang digelembungkan melalui diffuser. Disamping itu karena kadar besi awal lebih dari $1 \mathrm{mg} / \mathrm{L}$, maka reaksi oksidasi akan cukup lama sehingga perlu waktu lama atau memerlukan proses filtrasi untuk mempercepat proses oksidasi besi tersebut sampai tingkat konsentrasi yang diharapkan. Oksidasi besi dipengaruhi oleh jumlah oksigen yang bereaksi. Semakin merata dan semakin kecil gelembung udara yang dihembuskan ke dalam air, maka oksigen yang bereaksi semakin besar sehingga kadar besi dalam air mengalami penurunan (Batara, dkk., 2017). Setelah perlakuan menggunakan bubble aerator kadar besi yang diturunkan hanya sedikit, ini disebabkan karena jumlah oksigen yang bereaksi sedikit sehingga mempengaruhi oksidasi besi yang tidak optimal. Efisiensi penurunan kadar Fe pada bubble aerator dapat dilihat pada Tabel 4.

Tabel 4. Efisiensi Metode Aerasi Bubble Aerator Terhadap Penurunan Kadar Fe Dalam Air Sumur Bor

\begin{tabular}{|c|c|c|c|c|}
\hline \multirow{2}{*}{$\begin{array}{c}\text { Waktu } \\
\text { Menit) }\end{array}$} & \multicolumn{2}{|c|}{ Efisiensi Metode Aerasi Bubble Aerator (\%) } & \multirow{2}{*}{ Rata-rata } \\
\cline { 2 - 4 } & B1 & B2 & B3 & \\
\hline $\mathbf{2 0}$ & 2,19 & 0,48 & 0,66 & 1,11 \\
\hline $\mathbf{3 0}$ & 3,42 & 1,47 & 1,66 & 2,18 \\
\hline $\mathbf{4 0}$ & 6,13 & 4,28 & 3,42 & 4,61 \\
\hline
\end{tabular}


Dari hasil analisa bubble aerator menghasilkan nilai efisiensi yang lebih kecil dalam menurunkan kadar Fe air sumur bor dibandingkan dengan cascade aerator, hal ini dimungkinkan karena tidak adanya turbulensi air secara langsung seperti cascade aerator sehingga penurunan kadar besi pada bubble aerator hanya sedikit dan tidak maksimal. Efisiensi metode cascade aerator dan bubble aerator terhadap penurunan kandungan kadar besi $(\mathrm{Fe})$ dalam air sumur bor sebesar $50,45 \%$ sedangkan pada bubble aerator $6,13 \%$. Selisih efisiensi yang terjadi sebesar $44,32 \%$, dari selisih tersebut dapat diketahui bahwa adanya perbedaan antara cascade aerator dan bubble aerator, bahwa cascade aerator lebih baik dalam menurunkan kadar $\mathrm{Fe}$ air sumur bor. Cascade aerator memberikan hasil yang lebih baik dibandingkan bubble aerator, karena cascade aerator mempunyai luas bidang kontak antara air dan oksigen lebih besar dibandingkan bubble aerator, sehingga meskipun waktu kontak yang terjadi yaitu sama 20, 30 dan 40 menit tetapi jumlah oksigen yang dikontakkan lebih banyak.

\section{Perbandingan Penggunaan Cascade Aerator dan Bubble Aerator}

Uji analisis perbandingan yang digunakan untuk menguji perbandingan antara pengaruh penggunaan cascade aerator dan bubble aerator untuk menurunkan kadar Fe dalam air sumur bor. Untuk nilai rata-rata hasil percobaan bubble aerator dan cascade aerator dapat dilihat pada Tabel 5.

Tabel 5. Nilai Rata-Rata Hasil Percobaan Bubble Aerator dan Cascade Aerator

\begin{tabular}{|c|c|c|c|c|c|}
\hline \multirow{2}{*}{$\begin{array}{c}\text { Hasil } \\
\text { Percobaan }\end{array}$} & $\begin{array}{c}\text { Kelompok } \\
\text { Aerasi }\end{array}$ & $\mathbf{N}$ & Mean & $\begin{array}{c}\text { Standard } \\
\text { Deviation }\end{array}$ & $\begin{array}{c}\text { Standard } \\
\text { Error Mean }\end{array}$ \\
\cline { 2 - 6 } & $\mathrm{B}$ & 3 & 20,080 & 0,2914 & 0,1682 \\
\cline { 2 - 6 } & $\mathrm{C}$ & 3 & 10,623 & 0,3349 & 0,1933 \\
\hline
\end{tabular}

Berdasarkan tabel diatas diketahui nilai rata-rata hasil percobaan atau mean untuk kelompok B (bubble aerator) adalah sebesar 20,080, sementara untuk kelompok C (cascade aerator) adalah sebesar 10,623. Dengan demikian dapat disimpulkan ada perbedaan penggunaan bubble aerator dan cascade aerator dalam menurunkan kadar $\mathrm{Fe}$ air sumur bor, dimana efisiensi penurunan kadar Fe dengan menggunakan cascade aerator sebesar 50,45\% dengan nilai $\mathrm{K}_{\mathrm{La}}$ rata-rata sebesar 0,0103/menit, sedangkan efisiensi penurunan kadar Fe dengan menggunakan bubble aerator sebesar 6,13\% dengan nilai $\mathrm{K}_{\mathrm{L}}$ a rata-rata sebesar $0,0052 /$ menit.

Tabel 6. Hasil Output Independent Sampel Test Hasil Percobaan Bubble Aerator dan Cascade Aerator

\begin{tabular}{|c|c|c|c|c|c|c|c|c|c|c|}
\hline & \multicolumn{5}{|c|}{$\begin{array}{c}\text { Levene's Test for Equality of } \\
\text { Variances }\end{array}$} & \multicolumn{2}{|c|}{$\begin{array}{c}\text { T-test for Equality of } \\
\text { Means }\end{array}$} & \multicolumn{2}{|c|}{$\begin{array}{l}\text { 95\% Confidence } \\
\text { Interval of the } \\
\text { Difference } \\
\text { Lower Upper }\end{array}$} \\
\hline & & F & Sig. & $\mathrm{t}$ & $\mathrm{df}$ & $\begin{array}{l}\text { Sig. } \\
(2- \\
\text { tailed })\end{array}$ & $\begin{array}{c}\text { Mean } \\
\text { Difference }\end{array}$ & $\begin{array}{l}\text { Standard } \\
\text { Eror } \\
\text { Difference }\end{array}$ & Lower & Upper \\
\hline \multirow[b]{2}{*}{$\begin{array}{c}\text { Hasil } \\
\text { Percobaan }\end{array}$} & $\begin{array}{c}\text { Equal } \\
\text { variances } \\
\text { assumed }\end{array}$ & 0,204 & 0,675 & 36,900 & 4 & 0,000 & 9,4567 & 0,2563 & 8,7451 & 10,1682 \\
\hline & $\begin{array}{c}\text { Equal } \\
\text { variances } \\
\text { not } \\
\text { assumed }\end{array}$ & & & 36,900 & 3,925 & 0,000 & 9,4567 & 0,2563 & 8,7397 & 10,1736 \\
\hline
\end{tabular}

Berdasarkan Tabel 6. diketahui nilai Sig. Levene's Test for Equality of Variances adalah sebesar 0,675 > 0,05, maka dapat diartikan bahwa variansi data antara bubble aerator 
dan cascade aerator adalah homogen atau sama. Sehingga penafsiran tabel output di atas berpedoman pada nilai yang terdapat dalam tabel Equal Variances Assumed. Pada bagian Equal Variances Assumed diketahui nilai Sig. (2-tailed) sebesar 0,000 <0,05, maka dapat disimpulkan bahwa H0 ditolak dan Ha diterima. Dengan demikian dapat disimpulkan bahwa ada perbedaan yang signifikan (nyata) percobaan antara bubble aerator dengan cascade aerator.

Selanjutnya, dari Tabel 6. diketahui nilai Mean Difference adalah sebesar 9,4567. Nilai ini menunjukkan selisih antara rata-rata hasil percobaan pada bubble aerator dengan ratarata hasil percobaan pada cascade aerator yaitu 20,08 - 10,62 =9,4567 dan selisih perbedaan tersebut adalah 8,7451 sampai 10,1682 (95\% Confidence Interval of the Difference Lower Upper). Nilai t hitung positif disebabkan karena nilai rata-rata hasil percobaan pada bubble aerator lebih tinggi dari nilai rata-rata hasil percobaan pada cascade aerator.

Diketahui nilai t hitung sebesar 36,900 dan nilai t tabel yang didapat sebesar 2,776. Karena nilai t hitung sebesar 36,900 > t tabel 2,776, maka berdasarkan keputusan melalui perbandingan nilai t hitung dengan $\mathrm{t}$ tabel, dapat disimpulkan bahwa $\mathrm{H} 0$ ditolak dan $\mathrm{Ha}$ diterima, yang berarti ada perbedaan antara bubble aerator dengan cascade aerator. Dimana cascade aerator lebih efektif dalam menurunkan kadar Fe dalam air sumur bor.

\section{Hubungan Antara Lama Waktu Kontak Aerasi Dengan Penurunan Parameter Pencemar}

Analisis regresi linear sederhana yaitu analisis untuk mengetahui arah hubungan antara lama waktu kontak aerasi dengan penurunan parameter pencemar. Secara umum rumus persamaan regresi linear sederhana adalah $\mathrm{Y}=\mathrm{a}+\mathrm{bX}$. Sementara untuk mengetahui nilai koefisien regresi tersebut dapat dilihat pada Tabel 7.

Tabel 7. Nilai Koefisien Penurunan Parameter

\begin{tabular}{|c|c|c|c|c|c|c|}
\hline \multicolumn{2}{|c|}{} & \multicolumn{2}{c|}{$\begin{array}{c}\text { Unstandardized } \\
\text { Coefficients }\end{array}$} & \multicolumn{2}{|c|}{ Standardized Coefficients } \\
\hline \multicolumn{2}{|c|}{ Model } & B & $\begin{array}{c}\text { Standard } \\
\text { Error }\end{array}$ & Beta & t & Sig. \\
\hline \multirow{2}{*}{1} & (Constant) & 22,792 & 1,704 & & 13,375 & 0,000 \\
\cline { 2 - 7 } & $\begin{array}{c}\text { Lama waktu } \\
\text { kontak }\end{array}$ & $-0,298$ & 0,055 & $-0,899$ & $-5,428$ & 0,001 \\
\hline
\end{tabular}

Angka konstanta dari unstandardized coefficients (a), dalam penelitian ini nilainya sebesar 22,792. Angka ini merupakan angka konstanta yang mempunyai arti bahwa jika tidak ada lama waktu kontak (X) maka nilai konsisten penurunan parameter (Y) adalah sebesar 22,792 .

Angka koefisien regresi (b) memiliki nilai sebesar -0,298. Angka ini mengandung arti bahwa setiap penambahan $1 \%$ lama waktu kontak (X), maka penurunan parameter (Y) akan meningkat sebesar -0,298, karena nilai koefisien regresi bernilai minus (-), maka dengan demikian dapat dikatakan bahwa lama waktu kontak (X) berpengaruh terhadap penurunan parameter $(\mathrm{Y})$, sehingga persamaan regresinya adalah $\mathrm{Y}=22,792-0,298 \mathrm{X}$.

Berdasarkan pada Tabel 7. diketahui nilai signifikansi (Sig.) sebesar 0,001 lebih kecil dari probabilitas 0,05, sehingga dapat disimpulkan bahwa $\mathrm{H} 0$ ditolak dan Ha diterima, yang berarti bahwa ada pengaruh lama waktu kontak $(\mathrm{X})$ terhadap penurunan parameter $(\mathrm{Y})$. 
Diketahui nilai t hitung sebesar $-5,428$ dan nilai t tabel yang didapat sebesar 2,365. Karena nilai t hitung sebesar $-5,428$ lebih besar dari 2,365, sehingga dapat disimpulkan bahwa H0 ditolak dan Ha diterima, yang berarti bahwa ada pengaruh lama waktu kontak (X) terhadap penurunan parameter $(\mathrm{Y})$. Untuk mengetahui besarnya pengaruh lama waktu kontak $(\mathrm{X})$ terhadap penurunan parameter $(\mathrm{Y})$ dalam analisis regresi linear sederhana, dapat dilihat pada nilai R Square atau R2 yang terdapat pada output SPSS Tabel 8.

Tabel 8. Nilai R Square atau R2

\begin{tabular}{|c|c|c|c|c|}
\hline Model & $\mathbf{R}$ & $\boldsymbol{R}$ Square & $\begin{array}{c}\text { Adjusted } \boldsymbol{R} \\
\text { Square }\end{array}$ & $\begin{array}{c}\text { Standard } \\
\text { Error of the } \\
\text { Estimate }\end{array}$ \\
\hline 1 & 0,899 & 0,808 & 0,781 & 1,34248 \\
\hline
\end{tabular}

Dari output diatas diketahui nilai $R$ Square sebesar 0,808. Nilai ini mengandung arti bahwa pengaruh lama waktu kontak (X) terhadap penurunan parameter (Y) adalah sebesar $80,8 \%$ sedangkam $19,2 \%$ penurunan parameter dipengaruhi oleh variable yang lain. Maka dapat disimpulkan bahwa lama waktu kontak (X) berpengaruh negatif terhadap penurunan parameter (Y) dengan total pengaruh sebesar 80,8\%. Pengaruh negatif ini bermakna semakin lama waktu kontaknya maka akan berpengaruh terhadap penurunan parameternya.

\section{PENUTUP}

\section{A. Kesimpulan}

Kesimpulan yang dapat diambil dari penelitian ini, yaitu :

1. Penggunaan metode cascade aerator dan bubble aerator ada perbedaan, hal ini dapat dibuktikan berdasarkan uji analisis perbandingan bahwa ada perbedaan antara bubble aerator dengan cascade aerator. Dimana cascade aerator lebih efektif dalam menurunkan kadar Fe dalam air sumur bor.

2. Besar efisiensi penurunan kadar Fe dalam air sumur bor dengan menggunakan cascade aerator sebesar 50,45 \% dan besar efisiensi penurunan kadar Fe dalam air sumur bor dengan menggunakan bubble aerator sebesar $6,13 \%$.

3. Waktu kontak optimum cascade aerator untuk menurunkan kadar Fe dalam air sumur bor adalah 28 menit dengan efisiensi sebesar 49,53 \% dan waktu kontak optimum bubble aerator untuk menurunkan kadar Fe dalam air sumur bor adalah 40 menit dengan efisiensi sebesar 4,61\%.

\section{B. Saran}

Saran yang dapat disampaikan untuk penelitian selanjutnya, sebaiknya setelah proses aerasi ditambah menggunakan filter karbon aktif, supaya penurunan kadar $\mathrm{Fe}$ sesuai dengan standar baku mutu.

\section{UCAPAN TERIMA KASIH}

Penulis mengucapkan terimakasih kepada dosen pembimbing Ibu Dr. Rizki Purnaini, S.T., M.T dan Ibu Govira Christiadora Asbanu, S.Pd.Si, M.Sc atas bimbingan, masukan, serta saran dalam menyelesaikan Tugas Akhir ini serta kepada keluarga dan semua pihak yang terlibat telah banyak membantu penulis selama proses pengerjaan penelitian. 


\section{DAFTAR PUSTAKA}

Achmad, R., 2004. Kimia Lingkungan. ANDI : Yogyakarta.

Abuzar, S. S.; Putra, Y. D., dan Emargi, R. E., 2012. Koefisien Transfer Gas (Kla) Pada Proses Aerasi Menggunakan Tray Aerator Bertingkat 5 (Lima). Jurnal Teknik Lingkungan UNAND 9 (2) : 155-163.

Batara, K.; Zaman, B., dan Oktiawan, W., 2017. Pengaruh Debit Udara dan Waktu Aerasi Terhadap Efisiensi Penurunan Besi dan Mangan Menggunakan Diffuser Aerator Pada Air Tanah. Jurnal Teknik Lingkungan, 6 (1) : 1-10.

Effendi, H., 2003. Telaah Kualitas Air Bagi Pengelolaan Sumber Daya dan Lingkungan Perairan. Kanisius : Yogyakarta.

Faust, S.D., dan Aly, O.M., 1981. Chemistry of Natural Waters. Ann Arbor Science Publishers, Inc. Michigan. Pp. 399.

Harfadli, M.; Saud, M. I., dan Nikinah, I. C., 2019. Estimasi Koefisien Transfer Oksigen (KLa) Pada Metode Aerasi Fine Bubble Diffuser : Studi Kasus Pengolahan Air Lindi TPA Manggar Kota Balikpapan. Jurnal Sains Terapan, 5 (2) : 107-112.

Hartini, E., 2012. Efektivitas Cascade Aerator dan Bubble Aerator Dalam Menurunkan Kadar Mangan Air Sumur Gali. Jurnal Kesehatan Masyarakat, 8 (1) : 44-52.

Joko, T., 2010. Unit Produksi Dalam Sistem Penyediaan Air Minum. Cetakan Pertama, Graha Ilmu : Yogyakarta.

Kawamura, S., 2000. Integrated Design and Operation of Water Treatment Facilities. John Wiley and Sons : New York.

Kumalasari, F., dan Satoto., 2011. Teknik Praktis Mengolah Air Kotor Menjadi Air Bersih. Laskar Aksara : Bekasi.

Lutfihani, A., 2015. Analisis Penurunan Kadar Besi (Fe) dengan Menggunakan Tray Aerator dan Diffuser Aerator. Skripsi. Institut Teknologi Sepuluh Nopember : Surabaya.

Manurung, M.; Ivansyah, O., dan Nurhasanah., 2017. Analisis Kualitas Air Sumur Bor di Pontianak Setelah Proses Penjernihan Dengan Metode Aerasi, Sedimentasi dan Filtrasi. Prisma Fisika, 5 (1) : 45-50.

Mubarak, A., 2016. Keefektifan Waktu Aerasi Menggunakan Bubble Aerator Dalam menurunkan Kadar Besi (Fe) Air Sumur Desa Kebarongan Kemrajen Banyumas. Skripsi. Universitas Muhammadiyah : Surakarta

Parulian, A., 2009. Monitoring dan Analisis Kadar Aluminium dan Besi Pada Pengolahan Air Minum PDAM Tirtana di Sunggal. Tesis. Pascasarjana Universitas Sumatera Utara (USU) : Medan.

Peraturan Menteri Kesehatan Republik Indonesia Nomor 32 Tahun 2017 Tentang Standar Baku Mutu Kesehatan Lingkungan dan Persyaratan Kesehatan Air untuk Keperluan Higiene Sanitasi, Kolam Renang, Solus Per Aqua, dan Pemandian Umum.

Purba, M.F.D., dan Hartini, E., 2013. Penurunan Kandungan Zat Besi (Fe) Dalam Air Sumur Gali dengan Metode Aerasi. Jurnal Visikes, 12 (1) : 67-73.

Rozainy, M. R., Jamil, R., dan Adlan, M. N., 2015. A Review of Removal Iron and Manganese By Using Cascade Aeration Systems. Jurnal Teknologi (Sciences \& Engineering) 74 (11) : 69-76. 
Said, N.I., 2005. Metode Penghilangan Zat Besi dan Mangan di Dalam Penyediaan Air Minum Domestik. Jurnal Air Indonesia (JAI), 1(3) : 239-250.

Siagian, David., 2018. Efektivitas Cascade Aerator Dalam Penurunan Kontaminan Besi (Fe) Pada Air Sumur Gali di Desa Pantai Labu Kab. Deli Serdang. Public Health Journal, $5(1): 1-9$.

SNI 6989.58:2008 Tentang Metode Pengambilan Contoh Air Tanah.

Zairinayati dan Maftukhah, N.A., 2019. Efektivitas Pengolahan Air Bersih Menggunakan Tray Aerator Dalam Menurunkan Konsentrasi Fe, Mn, pH pada Air Sumur Gali. Jurnal 'Aisyiyah Medika, 3 (1) : 19-32. 